\title{
Impact of Wheelset Steering and Wheel Profile Geometry to the Vehicle Behavior when Passing Curved Track
}

Vladimír Hauser, Olena S. Nozhenko, Kateryna O. Kravchenko, Mária Loulová, Juraj Gerlici, Tomáš Lack Faculty of Mechanical Engineering, University of Zilina, Univerzitná 8215/1, 01026 Žilina. Slovak Republic. E-mail: vladimir.hauser@fstroj.uniza.sk, olena.nozhenko@fstroj.uniza.sk, kateryna.kravchenko@fstroj.uniza.sk, maria.loulova@fstroj.uniza.sk,juraj.gerlici@fstroj.uniza.sk, tomas.lack@fstroj.uniza.sk

Ride of vehicles along curved track is a serious technical problem, which for the long term requires attention of vehicle engineers as well as track designers. It is especially interesting to observe behavior of tram cars passing a curved track, because they should be able to pass arcs up to 17 meter radius. Ride of a vehicle along such strongly curved track is nowadays accompanied by significant wear in rail-wheel contact, increased bogie and track stress and by generation of noise. One of the key causes of this unfavorable phenomenon is an increase of slip velocities in rail-wheel contact. This paper is based on simulation analysis, which compares different ways of minimizing slip velocities and thus mitigating the impacts of passing vehicles on the track as well as on the car itself. Bogies with and without wheelset steer possibility were analyzed. Both bogies were also analyzed with wheel profiles of different delta $\mathbf{R}$ function course.

Keywords: wheelset steering mechanism, passing of vehicle trough transition curves, simulation analysis, creep velocities in wheel - rail contact.

\section{Acknowledgement}

This paper was created after the processing of the project "RAILBCOT - RAIL Vehicles Brake COmponents Test Stand", ITMS Code 26220220011 based on the support of Research and Development Operational Program financed by European Fund of a Regional Development. The work was also supported by the project No. APVV-0842-11: “Equivalent railway operation load simulator on the roller rig". Research-Educational Center of Rail Vehicles (VVCKV)

\section{References}

[1] BLATNICKÝ, M., DIŽO, J., TIMOŠČUK, M. (2016). Design of a three-finger robot manipulator. In: Manufacturing Technology: journal for science, research and production. - ISSN 1213-2489. - Vol. 16, no. 3 (2016), s. 485489.

[2] DIŽO, J. (2016). Analysis of a goods wagon running on a railway test track. In: Manufacturing Technology: journal for science, research and production. - ISSN 1213-2489. - Vol. 16, no. 4 (2016), s. 667-672.

[3] GERLICI, J., LACK, T., HAUSER, V., MAŇUROVÁ, M., NOZHENKO, O., S., KRAVCHENKO, K., O. (2016). The Wagon Bogie. Utility model application no. u 2016 09015. Classification B61F5/30. State enterprise "Ukrainian intellectual property institute" (UKRPATENT). Street Glazunova 1, 01601, Kijev 42. http://www.uipv.org /en/index.html, Registered on 2016/08/25.

[4] HAUSER, V. (2016). Effects of T3 tram bogie to the track when passing transition curves. In: Experimental and computational methods in engineering. Conference proceedings of the III. International scientific conference. 2016 jun 2.-3., Ústí nad Labem. ISBN 978-80-7561-004-1.

[5] HAUSER, V. (2016). Mitigate the effects of tram bogie transit on a track in a curve. In: Experimental and computational methods in engineering. Conference proceedings of the III. International scientific conference. 2016 jun 2.-3., Ústí nad Labem. ISBN 978-80-7561-004-1.

[6] HAUSER, V. (2015). Running of public transport vehicles through small radius track. In: Current problems in rail vehicles PRORAIL 2015, Proceedings of lectures, Žilina, 16.-18.9.2015, Slovak Republic, ISBN 978-80-8927648-6. - S. 199-206.

[7] POLACH, P. (2015). Influene of the Shock Absorbers Type Change at Stress of the Trolleybus Chassis. In: Manufacturing Technology. Vol. 15, No. 1, 2015. Pp. 77 - 86. ISSN 1213-2489

[8] SIMPACK A.G. (2016). Documentation to the program system SIMPACK.

[9] SVOBODA, M., SOUKUP, J. (2013). Dynamic measurement of four-axle railway wagon. In: Manufacturing Technology. 2013, vol. 13, iss. 4, (pp. 552-558). ISSN 1213-2489.

[10] SUCHÁNEK, A., HARUŠINEC, J. (2015). The downhill braked railway wheel structural analysis by means of the ANSYS multiphysics program system package. In: Manufacturing technology: journal for science, research and production. - ISSN 1213-2489. - Vol. 15, no. 5 (2015), s. 945-950. 